\title{
Penataan Ulang Infrastruktur PAUD dalam Rencana Pembukaan Kembali Sekolah di Masa Pandemi Covid-
} 19

\author{
Dianti Yunia Sari ${ }^{1 凶}$, Aldila Rahma ${ }^{1}$, Ine Rahaju ${ }^{2}$ \\ Pendidikan Guru Pendidikan Anak Usia Dini, Universitas Islam Nusantara, Indonesia(1) \\ Sekolah Pendidikan Anak Usia Dini Langgeng Garjita, Indonesia( ${ }^{(2)}$ \\ DOI: $10.31004 /$ obsesi.v6i2.1450
}

\begin{abstract}
Abstrak
Kebijakan pemerintah membuka kembali sekolah dimasa adaptasi kebiasaan baru (new normal) Pandemik Covid-19, mempengaruhi perubahan komponen struktural maupun non struktural sekolah. Tujuan dan fokus penelitian ini yaitu pada penataan ulang infrastruktur fisik, sebagai upaya mitigasi menjadikan sekolah aman dengan mengurangi transmisi virus dalam komunitas. Penelitian menggunakan pendekatan metode kualitatif dengan jenis studi kasus yang dilaksanakan di PAUD Langgeng Garjita, Cianjur, Jawa Barat. Data diperoleh melalui wawancara, observasi, dan dokumentasi. Analisis deskripsi dilakukan untuk memperoleh gambaran detail perbandingan infrastruktur sekolah sebelum dan rencana pembukaan kembali saat pandemik. Terdapat perubahan besar pada tata struktur lingkungan sekolah, termasuk juga pembuatan Standar Operasional Prosedur baru dalam penyambutan dan penjemputan anak, serta proses pembelajaran. Pembukaan kembali sekolah dirancang dengan mengikuti syarat protokol kesehatan yang ditetapkan pemerintah. Diperlukan instruksi yang konsisten dan lingkungan pengasuhan yang jelas, agar anak mampu menyesuaikan diri dan berkembang dalam lingkungan belajar yang baru.
\end{abstract}

Kata Kunci: pembukaan kembali; new normal; mitigasi; anak usia dini; Covid-19

\begin{abstract}
The government's policy to reopen schools during the adaptation of new normal to the Covid19 Pandemic affects changes in schools' structural and non-structural components. The purpose and focus of this research are on rearranging physical infrastructure as a mitigation effort to make schools safe by reducing virus transmission in the community. The research used a qualitative method approach with a case study type carried out at PAUD Langgeng Garjita, Cianjur, West Java Province. Data obtained through interviews, observation, and documentation. Description analysis was carried out to obtain a detailed comparison picture of the school infrastructure before and plans for reopening during the pandemic. There have been significant changes to the school environment's structure, including making a new Standard Operating Procedure (SOP) for welcoming and picking up children and the learning process. The reopening of schools is designed to follow the health protocol requirements set by the government. In addition, consistent instruction and a distinct parenting environment are needed so that children can adapt and thrive in a new learning environment.
\end{abstract}

Keywords: school reopening; new normal; mitigation; early childhood; Covid-19

Copyright (c) 2021 Dianti Yunia Sari, et al.

$\triangle$ Corresponding author

Email Address: dianti.yuniasari@fkip-uninus.ac.id (Bandung, Indonesia)

Received 4 January 2021, Accepted 19 June 2021, Published 12 October 2021 


\section{PENDAHULUAN}

Dalam rangka menghadapi menghadapi pandemik Covid-19, Pemerintah Indonesia menghimbau semua pihak untuk menerapkan protokol kesehatan $5 \mathrm{M}$ yaitu, memakai masker, menjaga jarak, mencuci tangan, menghindari kerumunan, dan mengurangi mobilitas (Alfarizi 2020). Hal tersebut dilakukan sebagai usaha untuk mencegah penyebaran Covid-19. Dunia pendidikan menjadi sektor yang paling terdampak pandemik. Berdasarkan laporan UNESCO, lebih dari 1,5 milyar peserta didik di hampir 165 negara terdampak akibat penutupan (lockdown) sekolah dan kampus (Osman 2020). Memang masih jarang bukti yang mendukung efektivitas penutupan sekolah dalam pengenalian Covid-19. Belum diketahui sejauh mana anak sekolah rentan terhadap penularan Covid-19 (Viner et al. 2021). Namun demikian menurut Kementerian Kesehatan Republik Indonesia, anak-anak, lanjut usia, dan orangorang yang memiliki kormobiditas adalah bagian kelompok rentan terpapar virus (Menteri Kesehatan Republik Indonesia 2020).

Jika melihat perkembangan kondisi pandemik, pembukaan kembali sekolah sekaligus mencegah penyebaran virus memiliki risiko tinggi dan harus mempertimbangkan banyak hal. Prioritas utama yaitu, memastikan keselamatan dan keamanan semua orang termasuk anak, orang tua, guru, dan komunitas sekolah. Kriteria berikutnya yaitu berkaitan dengan perlindungan fisik terhadap virus. Sekolah yang dibuka adalah yang berada di daerah minim terdampak atau yang memiliki fasilitas kebersihan dan kesehatan memadai. Sekolah juga harus diatur ulang baik dari pangaturan lingkungan, maupun shift (rotasi) dari penghuni sekolah. Terakhir, menentukan siapa dulu yang kembali ke sekolah, apakah berdasarkan tingkat usia atau dengan pendekatan geografis, misalnya prioritas di tempat yang berpenduduk sedikit atau daerah yang tingkat kemiskinannya tinggi (UNESCO 2020).

Pembukaan kembali sekolah khususnya untuk jenjang pendidikan anak usia dini (PAUD) tentunya membutuhkan banyak pertimbangan khusus. Pertimbangan unik terkait pengaturan dengan pendekatan holistik termasuk memberikan dukungan emosional, kesempatan belajar, dan menawarkan pengasuhan anak yang handal bagi orang tua yang kembali bekerja (United Nations Children's Fund, World Bank and United Nations Educational, Scientific and Cultural Organization 2020). Berdasarkan hal tersebut, sekolah memerlukan strategi untuk tercapainya proses pembelajaran agar sesuai dengan apa yang sudah di programkan. Pandemik Covid-19 membatasi interaksi antara orang-orang, sehingga diperlukan tindakan respon yang memungkinkan fleksibilitas dalam mengubah dan menata kembali lingkungan belajar. Tujuannya agar memastikan pembelajaran tetap berlangsung dengan tetap memperhatikan faktor keamanan, kesehatan, dan keselamatan bersama.

Semua institusi pendidikan dari jenjang pendidikan dasar sampai pendidikan tinggi masih menutup sekolah sampai saat ini (Juni 2021). Melalui Surat Keputusan Bersama Menteri Pendidikan dan Kebudayaan, Menteri Agama, Menteri Kesehatan, dan Menteri Dalam Negeri Republik Indonesia, Tentang Panduan Penyelenggaraan Pembelajaran Pada Tahun Pelajaran 2020/2021 di Masa Pandemik Covid-19, Pemerintah Indonesia mengumumkan bahwa institusi pendidikan direncanakan akan melakukan pembelajaran tatap muka secara terbatas dimulai pada Juli 2021 (Sari and Purnamasari 2021). Dengan demikian, pemerintah daerah membuat aturan turunannya agar lebih mudah diimplementasikan oleh sekolah. Salah satunya, Dinas Pendidikan dan Kebudayaan Pemerintah Kabupaten Cianjur melalui surat edaran Nomor 420/529/Disikbud/VI/2021, memberikan arahan perihal pembelajaran tatap muka. Semua jenjang pendidikan dasar dari TK, PAUD, SD, SMP, SKB, dan Pendidikan Kesetaraan perlu menyesuaikan konsep dan rencana pembelajaran tatap muka di masa Pandemi Covid. Dengan demikian, institusi pendidikan termasuk PAUD diharuskan untuk menata ulang sekolah mereka sehingga memenuhi protokol kesehatan yang ditetapkan pemerintah (Pemerintah Kabupaten Cianjur, 2021).

PAUD Langgeng Garjita terletak di Kampung Jolok Cianjur-Cipanas, Provinsi Jawa Barat. Berdasarkan hasil wawancara dengan pihak sekolah, PAUD ini sering digunakan sebagai percontohan. Sekolah ini pernah digunakan untuk kegiatan seperti; (1) pelatihan calon 
pelatih (PCP) tingkat dasar, lanjut dan mahir serta pelatihan calon pelatih dan pengelola (PCP) menuju PAUD berkualitas pada tahun 2018; (2) pelatihan model pembelajaran (Eksistensi, Science, Technology, Enginering, Art, and Math (ESTEAM) dan Looseparts pada tahun 2019; (3) tempat studi banding model pembelajaran ESTEAM tahun 2019; (4) tempat penelitian atau magang mahasiswa; dan (5) kegiatan parenting. Hal ini yang melandasi pemilihan sekolah ini sebagai lokasi penelitian. Saat ini PAUD Langgeng Garjita sedang mempersiapkan untuk pembukaan kembali sekolah di masa adaptasi kebiasaan baru Pandemik Covid-19. Meskipun demikian, prinsip kehati-hatian tetap harus diutamakan dalam dalam rencana pembukaan sekolah. Kunci terpenting adalah peran guru dalam menjamin keberlangsungan kegiatan pembelajaran. Guru harus mengetahui fakta-fakta terkait Covid untuk dapat melindungi diri dan murid-muridnya. Memahami bagaimana penyebaran virus dan cara melindungi diri sendiri serta orang lain adalah langkah pertama dalam membangun prosedur dan protokol kesehatan di sekolah (UNICEF 2020).

Hal lain yang harus diperhatikan dalam pembukaan kembali sekolah diantaranya; kegiatan olah raga dan ekstrakulikuler belum diperbolehkan, guru dan tenaga pendidik harus sudah menerima vaksinasi, selain itu tatap muka bisa dihentikan jika terjadi kasus baru di sekolah tersebut (Caesaria 2021). Untuk jenjang PAUD, kelas dikondisikan jaga jarak minimal 1,5 meter dan maksimal hanya 5 peserta didik per kelas. Adapun jumlah hari dan jam sekolah termasuk dalam diskresi masing-masing sekolah sesuai dengan kebutuhan (Bramasta 2021). Tabel 1 menyajikan contoh pengaturan ruang kelas di berbagai negara selama pandemik.

Tabel 1. Pengaturan Ruang Kelas dari Berbagai Negara Selama Pandemik Covid-19

\begin{tabular}{|c|c|c|c|c|c|}
\hline & China & Denmark & Norwegia & Singapura & Taiwan \\
\hline $\begin{array}{l}\text { Ukuran } \\
\text { Kelompok/ } \\
\text { Staffing }\end{array}$ & $\begin{array}{l}\text { Ukuran kelas } \\
\text { dikurangi } \\
\text { dari } 50 \\
\text { menjadi } 30 \text { di } \\
\text { beberapa } \\
\text { daerah }\end{array}$ & $\begin{array}{l}\text { Kelas dikurangi } \\
\text { untuk } \\
\text { mengakomodasi } \\
\text { jarak tiap } 2 \\
\text { meter dalam } \\
\text { kelas }\end{array}$ & $\begin{array}{l}\text { Kelas } \\
\text { maksimum } \\
\text { berisi } 15 \\
\text { untuk } \\
\text { tingkat } \\
\text { kelas 1-4, } \\
\text { dan } 20 \\
\text { untuk kelas } \\
5-7\end{array}$ & $\begin{array}{l}\text { Tidak ada } \\
\text { ukuran } \\
\text { maksimum kelas. } \\
\text { Kelas sudah } \\
\text { cukup luas untuk } \\
\text { memastikan } \\
\text { pemisahan jarak } \\
\text { 1-2 meter }\end{array}$ & $\begin{array}{l}\text { Tidak ada } \\
\text { ukuran } \\
\text { maksimum } \\
\text { kelas. Siswa } \\
\text { tetap dalam } \\
\text { kelas. Guru } \\
\text { mata } \\
\text { pelajaran } \\
\text { yang } \\
\text { berpindah } \\
\text { antar kelas. }\end{array}$ \\
\hline $\begin{array}{l}\text { Pengaturan } \\
\text { ruang kelas }\end{array}$ & $\begin{array}{l}\text { Memecah } \\
\text { kelompok } \\
\text { dan } \\
\text { menggunakan } \\
\text { pemisah fisik }\end{array}$ & $\begin{array}{l}\text { Physical } \\
\text { distancing }(2 \mathrm{~m}) \\
\text { dalam kelas, } \\
\text { menggunakan } \\
\text { ruang outdoor }\end{array}$ & $\begin{array}{l}\text { Physical } \\
\text { distancing } \\
\text { dalam kelas, } \\
\text { dan } \\
\text { penggunaan } \\
\text { ruang } \\
\text { outdoor }\end{array}$ & $\begin{array}{l}\text { Pemisahan meja } \\
\text { yang } \\
\text { berkelompok, } \\
\text { mempertahankan } \\
\text { jarak 1-2 meter. }\end{array}$ & $\begin{array}{l}\text { Pemisahan } \\
\text { meja } \\
\text { berkelompok, } \\
\text { menggunakan } \\
\text { pemisah fisik }\end{array}$ \\
\hline
\end{tabular}

Sumber : (Melnick et al. 2020)

Mitigasi berlapis secara substansial dengan menjadikan sekolah lebih aman sejalan dengan pengurangan transmisi virus dalam komunitas sekolah dan rumah tangga, adalah konsep penting dalam membuka kembali sekolah (Gurdasani et al. 2021). Penelitian ini bertujuan untuk memberikan contoh studi kasus penataan ulang infrastruktur fisik sekolah dalam rangka persiapan pembukaan kembali sekolah PAUD di masa pandemik. Penelitian ini dibatasi pada penataan dan perancangan ulang lingkungan belajar baru di era Covid-19, disesuaikan dengan pedoman kesehatan nasional. 


\section{METODOLOGI}

Penelitian menggunakan metode penelitian kualitatif dengan pendekatan studi kasus observasi. Pendekatan studi kasus dipilih untuk menggali informasi secara mendalam pada suatu fenomena (Farquhar 2012). Penelitian ini bersifat komprehensif, merinci, dan mendalam untuk mengkaji dan diharapkan memberikan kontribusi berupa model penataan ulang infrastuktur lembaga PAUD dalam rencana pembukaan kembali sekolah. Penelitian hanya menggunakan satu unit lembaga untuk menjadi fokus perhatian. PAUD Langgeng Garjita berlokasi di Kampung Jolok, Desa Sindangjaya, Kecamatan Cipanas, Jawa Barat.

Penelitian ini mendeskripsikan penataan ulang lingkungan belajar sebagai adaptasi kebiasaan baru di masa Pandemik Covid-19. Penelitian persiapan tatap muka dibuka PAUD Langgeng Garjita dilakukan pada bulan Oktober 2020-Maret 2021. Pengumpulan data dilakukan melalui observasi, wawancara, dan dokumentasi. Peneliti terlibat dalam observasi, mulai dari perencanaan penataan ulang infrastuktur PAUD, sampai pada simulasi langsung oleh siswa dan guru secara bertahap. Wawancara dengan informan kunci yang terdiri dari pendidik dan tenaga kependidikan berjumlah 6 orang, untuk mengetahui secara rinci perubahan penataan infrastuktur sekolah dan juga pembuatan standar operasional prosedur (SOP) adaptasi kebiasaan baru. Adapun dokumentasi digunakan untuk menambah pemahaman atau informasi yang diperlukan dalam penelitian.

Data catatan wawancara, catatan lapangan, dan catatan dokumen (data sekunder) yang diperoleh kemudian dianalisis. Deskripsi analisis digunakan untuk memberi gambaran secara spesifik, bagaimana perubahan penataan struktur lingkungan sekolah saat sebelum dan saat rencana pembukaan kembali sekolah saat Pandemik.

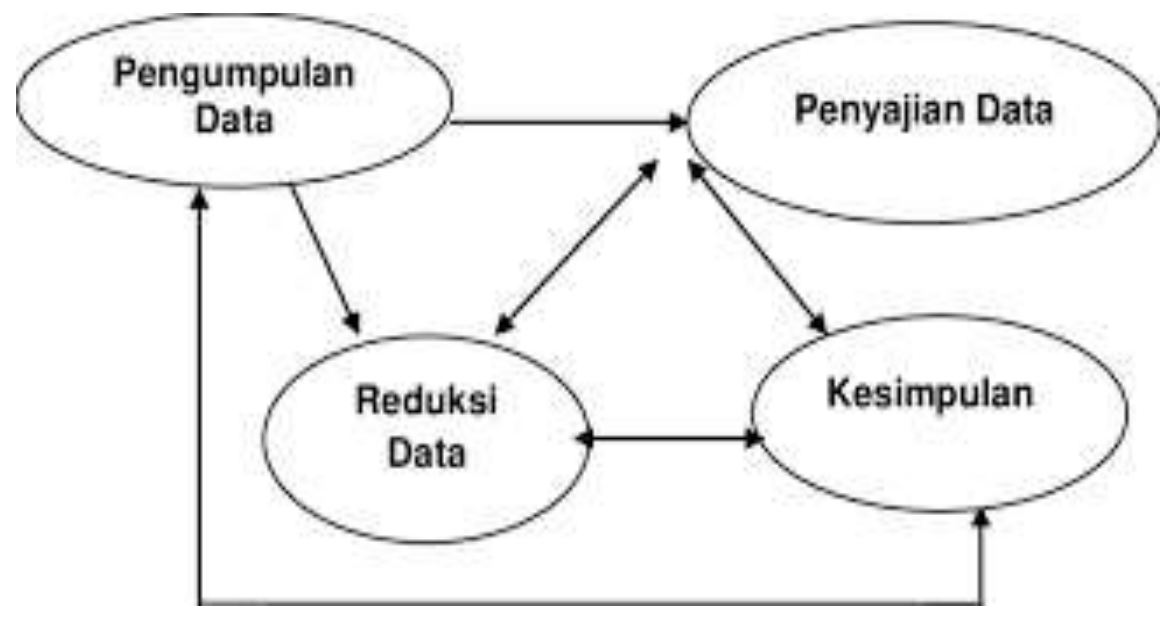

Bagan 1. Bagan analisis data kualitatif (adaptasi dari Miles and Huberman, 2004)

\section{HASIL DAN PEMBAHASAN}

Pelaksanaan pembelajaran dimasa pandemik dilakukan melalui media online (daring). Semua kebutuhan belajar anak seperti media belajar difasilitasi oleh guru dengan cara dikirim ke setiap rumah melalui kurir yang sudah ditunjuk oleh pihak sekolah, setiap seminggu sekali. Tentunya dengan tetap memperhatikan protokol kesehatan. Dalam hal ini, penyediaan lingkungan belajar diserahkan kepada orang tua siswa, namun tetap mendapatkan bimbingan dan pengarahan dari pendidik melalui platform Whatsapp, Zoom, atau Google Meet. Pembelajaran melalui media online ini dilaksanakan dari bulan Maret 2020 dan masih berlangsung sampai saat ini (Juni 2021). Di PAUD Langgeng Garjita terdapat 3 kelompok peserta didik yang terdiri dari Kelompok A (anak usia 2-4 tahun), Kelompok B (anak usia 4-5 tahun), dan kelompok C (anak usia 5-6 tahun). 
Dalam kondisi nomal sebelum terjadi pandemik, ruangan di sekolah digunakan sebagaimana fungsinya. Banyak kegiatan yang dilakukan bersama dalam satu ruangan dan melibatkan banyak orang. Adapun gambaran kondisi awal pembagian ruangan saat kondisi normal sebelum pandemik yaitu, terdapat lima ruang kelas sentra yang terdiri dari sentra persiapan, sentra Imtaq, sentra balok, sentra alam, dan sentra bermain peran. Tiap sentra dapat memfasilitasi sampai 15 anak. Alat permainan edukatif di tiap sentra digunakan bersama-sama dalam satu ruangan dengan jarak antara kesempatan main antar sentra sangat dekat. Biasanya dalam satu sentra dilakukan 11-15 kegiatan bermain. Selama satu minggu, anak bergantian belajar dan bermain di lima sentra tersebut. Semua peserta didik dan guru menggunakan ruang makan di area terbuka secara bersama-sama dengan duduk saling berhadapan. Musholla (prayer room) digunakan bersana-sama dan untuk cuci tangan atau wudhu menggunakan keran dengan jarak kurang dari 1 meter. Ruang Aula berukuran besar biasanya digunakan bersama untuk kegiatan parenting dengan orang tua siswa.

PAUD Langgeng Garjita berencana melakukan pembelajaran tatap muka kembali pada tahun pelajaran 2021-2022, dengan tetap mempertimbangkan faktor kesehatan, kemananan, dan keselamatan bersama. Dalam rangka pembukaan kembali sekolah, institusi merekayasa pengaturan ruangan baik indoor maupun outdoor. Kapasitas lingkungan fisik yang disesuaikan dengan adaptasi kebiasaan baru yaitu dengan mengubah ruangan yang ada, dan difungsikan menjadi ruangan baru. Gambar 1 menunjukkan denah sekolah dan perubahan fungsionalnya, termasuk denah kelas yang akan digunakan pada saat new normal atau adaptasi kebiasaan baru. Tabel 2 menyajikan perubahan tata letak ruangan sebelum pandemik, saat rencana pembukaan kembali sekolah, dan keterangan dari gambar 1.

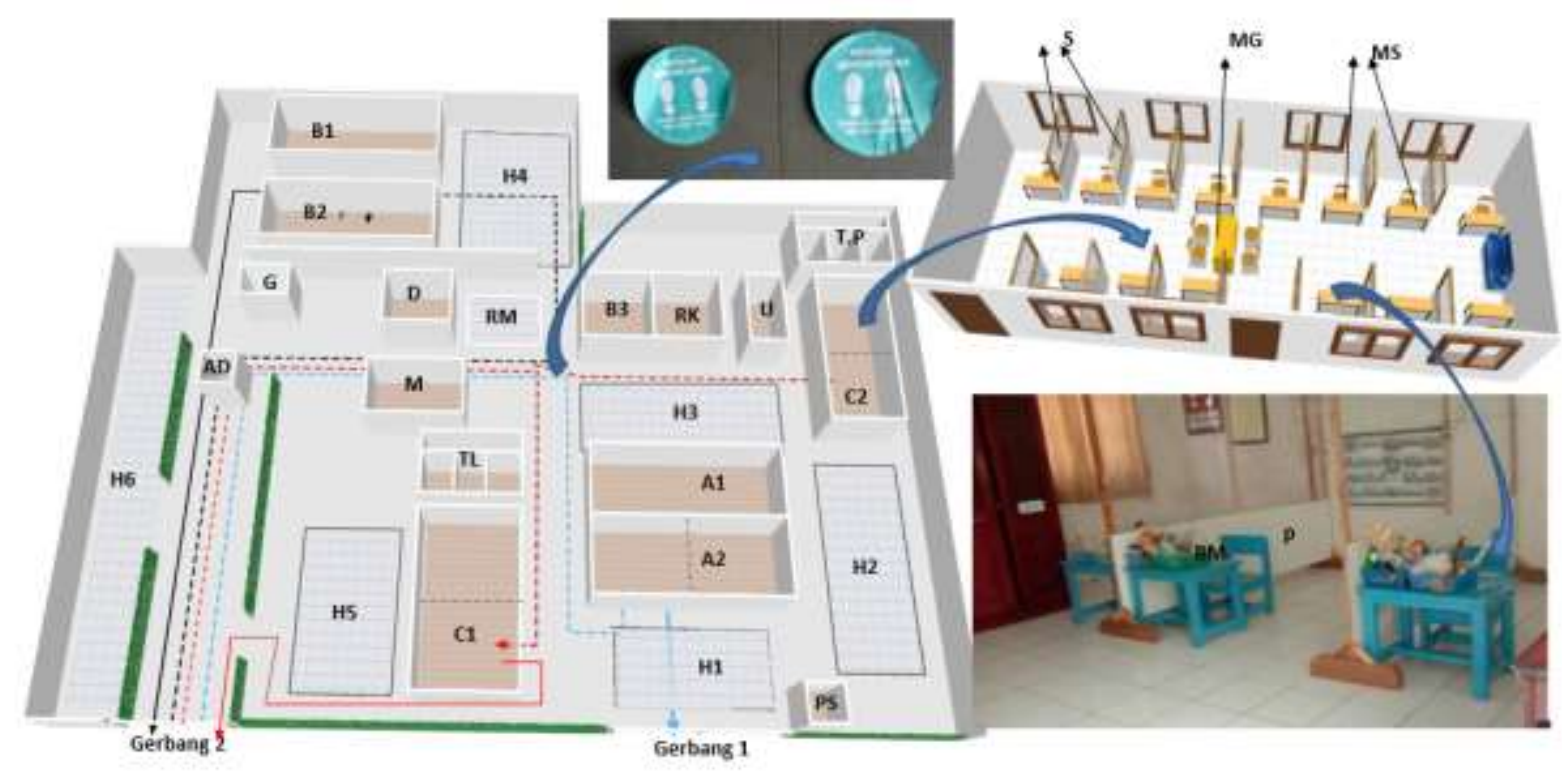

Gambar 1. Denah bangunan, penataan kembali kelas, dan jalur mobilitas keluar masuk sebagai bagian rencana pembukaan kembali sekolah

Berdasarkan tabel 2, beberapa ruang kelas berasal dari dua ruangan yang digabungkan (sekat antar kelas dibuka). Sebagai contoh ruang C2 awalnya adalah sentra balok dan sentra bermain peran, kemudian dua ruang tersebut digabung menjadi satu ruang kelas baru. Siswa kelompok $\mathrm{B}$ dan kelompok $\mathrm{C}$ masing-masing dibagi menjadi dua kelas untuk mengurangi kepadatan, dan belajar berdasarkan shift (pagi dan siang). Adapun kelompok A tetap, sebab memiliki jumlah anak yang sedikit.

Untuk menunjang kegiatan pembelajaran, sekolah menetapkan Standar Operasional Prosedur (SOP) dengan tetap menerapkan protokol kesehatan 5M (memakai masker, menjaga jarak, mencuci tangan, menghindari kerumunan, dan mengurangi mobilitas). Dalam ruang kelas yang baru dibuat sekat (semacam cubicle panel) dimana setiap anak menempati bilik-bilik 
tersebut, sehingga diharapkan akan mengurangi interaksi dan mobilitas. Di setiap bilik, sudah disediakan perlengkapan sanitasi dan juga APE (Alat Peraga Edukatif) pribadi, sehingga tidak ada penggunaan barang bersama. Adapun tanda panah menunjukkan alur keluar masuk sekolah. Alur keluar masuk direkayasa agar tidak terjadi kerumunan siswa maupun orang tua. Alur keluar masuk ini ditandai dengan stiker bergambar jejak kaki yang ditempelkan di lantai sekolah.

Tabel 2. Keterangan Gambar Perubahan Penataan Ruang Sebelum Pandemik dan Rencana Saat Pembukaan Kembali Sekolah

\begin{tabular}{|c|c|c|c|}
\hline Kode & \multicolumn{2}{|l|}{ Sebelum Pandemik } & Rencana Pembukaan Saat New Normal \\
\hline B1 & \multicolumn{2}{|l|}{ Aula 1} & Ruang kelas B1 \\
\hline B2 & \multicolumn{2}{|l|}{ Aula 2} & Ruang kelas B2 \\
\hline B3 & \multicolumn{2}{|l|}{ Ruang parenting } & Ruang tunggu orang tua siswa kelas B \\
\hline H1 & \multicolumn{2}{|l|}{ Halaman } & Halaman \\
\hline $\mathrm{H} 2$ & \multicolumn{2}{|l|}{ Halaman } & Halaman \\
\hline H3 & \multicolumn{2}{|l|}{ Halaman } & Halaman \\
\hline $\mathrm{H} 4$ & \multicolumn{2}{|l|}{ Halaman } & Halaman \\
\hline H5 & \multicolumn{2}{|l|}{ Halaman } & Halaman \\
\hline H6 & \multicolumn{2}{|l|}{ Halaman } & Halaman \\
\hline $\mathrm{AD}$ & \multicolumn{2}{|l|}{-} & Presensi, thermogun, dan desinfektan \\
\hline G & \multicolumn{2}{|l|}{ Gudang } & Gudang \\
\hline $\mathrm{D}$ & \multicolumn{2}{|l|}{ Dapur } & Dapur \\
\hline M & \multicolumn{2}{|l|}{ Mushalla } & Mushalla \\
\hline $\mathrm{RM}$ & \multicolumn{2}{|l|}{ Ruang makan (outdoor) } & Tidak difungsikan \\
\hline TL & \multicolumn{2}{|l|}{ Toilet dan wudhu laki-laki } & Toilet dan wudhu laki-laki \\
\hline $\mathrm{TP}$ & \multicolumn{2}{|l|}{ Toilet dan wudhu perempuan } & Toilet dan wudhu perempuan \\
\hline A1 & \multicolumn{2}{|c|}{ Penyimpanan alat dan bahan sentra alam } & Ruang tunggu orang tua siswa kelas A \\
\hline A2 & \multicolumn{2}{|c|}{ Sentra alam dan ruang guru (disekat) } & Ruang Kelas A (sekat ruang dibuka) \\
\hline $\mathrm{C} 1$ & \multicolumn{2}{|c|}{ Sentra persiapan dan sentra imtaq (disekat) } & Ruang kelas C1 (sekat ruang dibuka) \\
\hline $\mathrm{C} 2$ & \multicolumn{2}{|c|}{$\begin{array}{l}\text { Sentra balok dan sentra bermain peran } \\
\text { (disekat) }\end{array}$} & Ruang kelas C2 (sekat ruang dibuka) \\
\hline RK & \multirow{2}{*}{\multicolumn{2}{|c|}{$\begin{array}{l}\text { Ruang kepala sekolah } \\
\text { UKS }\end{array}$}} & Ruang kepala sekolah \\
\hline $\mathrm{U}$ & & & UKS \\
\hline$S$ & & Sekat plastik \\
\hline MG & & & Meja, kursi Guru \\
\hline MS & & & Meja, kursi Siswa \\
\hline $\mathrm{BM}$ & & & Box mainan anak (dari 5 sentra) \\
\hline $\mathrm{P}$ & & & Papan tulis \\
\hline PS & \multicolumn{2}{|l|}{ Pos Keamanan } & Pos Keamanan \\
\hline & Keterangan tanda panah & $\begin{array}{l}\longrightarrow \\
\longrightarrow \\
\longrightarrow \\
----\rightarrow \\
----\rightarrow \\
----\rightarrow\end{array}$ & $\begin{array}{l}\text { Alur keluar siswa dan orang tua kelas A } \\
\text { Alur keluar siswa dan orang tua kelas B } \\
\text { Alur keluar siswa dan orang tua kelas C } \\
\text { Alur masuk siswa dan orang tua kelas A } \\
\text { Alur masuk siswa dan orang tua kelas B } \\
\text { Alur masuk siswa dan orang tua kelas C }\end{array}$ \\
\hline
\end{tabular}

Perubahan struktur penataan ruang kelas dalam rangka adaptasi kebiasaan baru, tentunya mengubah fungsinya juga. Sebelum pandemik, PAUD Langgeng Garjita menyediakan sebelas kegiatan bermain di setiap sentra (imtaq, persiapan, peran, balok, dan alam). Prinsip terbuka diterapkan di setiap sentra, yaitu dari satu kegiatan bermain ke kegiatan bermain lainnya dilakukan tanpa adanya penyekat, sehingga setiap anak bebas memilih kegiatan bermain yang disediakan. Setiap sentra menggunakan satu ruang kelas tersendiri. Adapun dalam rencana pembukaan sekolah kembali, ruang sentra ditiadakan dan diubah menjadi kelas baru. 
Di dalam ruang kelas baru, dibangun bilik-bilik yang disekat menggunakan plastik di bagian atas dan bagian bawahnya terbuat dari papan, sehingga dapat difungsikan menjadi papan tulis. Terdapat 10-15 bilik per kelas dimana satu bilik akan ditempati oleh satu anak. Per bilik sudah disediakan APE yang sesuai dengan lima sentra (imtaq, persiapan, peran, balok dan alam). Bilik ini nantinya berfungsi sebagai tempat aktivitas belajar dan bermain anak. Selain APE, di setiap bilik dilengkapi dengan kebutuhan protokol kesehatan seperti hand sanitizer dan tissue. Guru menata alat dan bahan dalam satu wadah dan diletakkan di dalam bilik.

Penataan kelas dengan memberi jarak dan menggunakan penyekat dengan plastik, sudah mulai menjadi hal umum dilakukan di sekolah. Di Sekolah di Amerika, letak bangku diatur agar berjarak $6 \mathrm{kaki}$, menambahkan kipas untuk meningkatkan ventilasi, HEPA penjernih udara, dan juga menggunakan plastik penyekat. Sekolah juga menyediakan botol sanitizer, spray desinfektan, dan sarung tangan. Penggunaan masker dan pelindung wajah (face shield) sudah menjadi suatu kewajiban (Wise 2020). Begitu pula di Denmark dan Singapura, mnenerapkan jarak 1-2 meter antar bangku, dan mengurangi jumlah siswa dalam kelas menjadi 10-11 anak (Melnick et al. 2020).

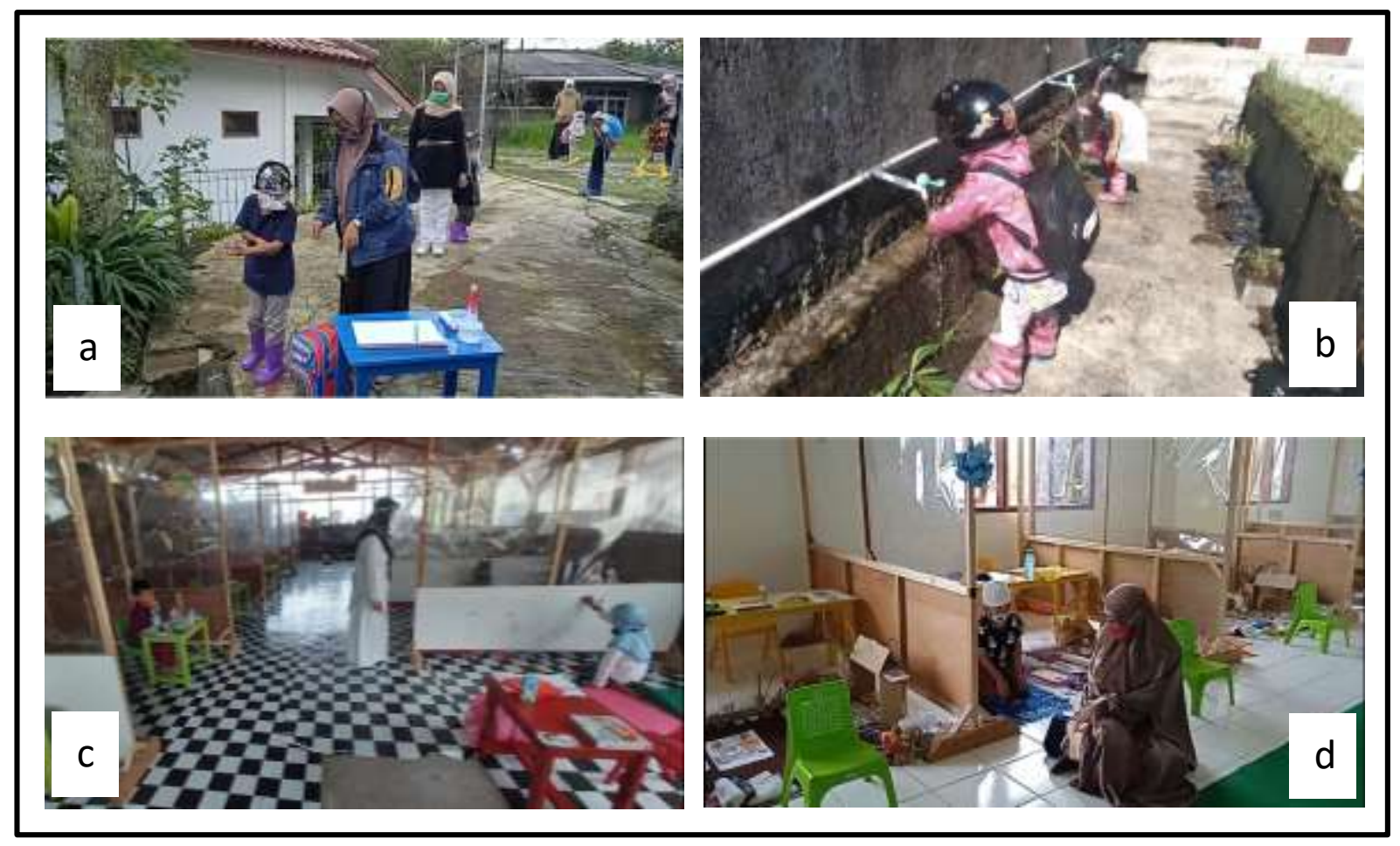

Gambar 2. Simulasi pembukaan kembali sekolah di masa Pandemik. Keterangan: (a) presensi, sanitasi, dan cek suhu tubuh; (b) cuci tangan, tetap berjarak; (c) (d) kegiatan belajar mengajar, siswa tetap di bilik masing-masing, guru mendatangi siswa.

Untuk meminimalkan permukaan benda tersentuh banyak orang, sebaiknya pintu kelas tetap dibuka atau ditutup setelah semua orang masuk. Loker diusahakan tidak digunakan terutama jika terletak di lorong bersama, sehingga membuat jarak fisik sulit dihindarkan. Permukaan benda yang sering disentuh seperti gagang pintu, keran air, wastafel, dan peralatan bersama lainnya harus rutin dibersihkan setiap hari dan sesering mungkin. Begitu pula dengan area bermain outdoor. Kebersihan tangan harus ditekankan sebelum dan sesudah penggunaan peralatan main. Peralatan main outdoor harus dibersihkan dan didesinfeksi secara teratur jika digunakan terus menerus (American Academy of Pediatrics 2021).

Adapun deskripsi perencanaan pembukaan pembukaan kembali sekolah PAUD Langgeng Garjita di masa adaptasi kebiasaan baru Pandemik Covid-19 diintegrasikan dalam 
Standar Operasional Prosedur (SOP). Prosedur ini terdiri dari SOP penyambutan anak, penjemputan, dan prosedur pembelajaran, yang disajikan pada tabel 3 dan tabel 4 .

Tabel 3. Standar Operasional Prosedur (SOP) Penyambutan dan Penjemputan Anak

\begin{tabular}{|c|c|}
\hline SOP Penyambutan Anak & SOP Penjemputan Anak \\
\hline $\begin{array}{l}\text { a. Orang tua wajib menggunakan masker pada saat datang ke } \\
\text { sekolah. } \\
\text { b. Anak wajib menggunakan masker dan sepatu boots yang } \\
\text { sudah disediakan. } \\
\text { c. Di pintu gerbang, anak dan orang tua mengukur suhu } \\
\text { badan secara mandiri dan menuliskannya di daftar suhu } \\
\text { badan harian. } \\
\text { d. Guru dan anak memberikan salam dengan simbol tangan } \\
\text { kiri diletakkan di kepala dan tangan kanan diletakkan di } \\
\text { dada. } \\
\text { e. Orang tua dan anak masuk pada bilik desinfektan untuk } \\
\text { mensterilkan seluruh permukaan tubuh. } \\
\text { f. Anak dan orang tua masuk ke kelas dengan mengikuti alur } \\
\text { yang telah disediakan dengan tetap menjaga jarak. } \\
\text { g. Anak mencuci sepatu boots dan tangan di tempat yang } \\
\text { telah disediakan. } \\
\text { h. Anak menyimpan jaket dan sepatu boots di tempat yang } \\
\text { telah disediakan. } \\
\text { i. Anak masuk ke dalam kelas langsung pada bilik belajar } \\
\text { masing-masing. } \\
\text { j. Orang tua menunggu di ruang tunggu yang telah } \\
\text { disediakan }\end{array}$ & $\begin{array}{l}\text { a. Guru mempersilakan anak } \\
\text { keluar satu persatu sesuai } \\
\text { dengan antrian orang tua di } \\
\text { muka kelas dengan tetap } \\
\text { menjaga jarak. } \\
\text { b. Guru dan anak memberikan } \\
\text { salam dengan tanpa } \\
\text { bersentuhan menggunakan } \\
\text { kan simbol tangan kiri } \\
\text { diletakkan di atas kepala dan } \\
\text { tangan kanan di letakkan di } \\
\text { dada. } \\
\text { c. Anak menggunakan jaket dan } \\
\text { sepatu sendiri kemudian } \\
\text { pulang sesuai dengan alur } \\
\text { kepulangan yang telah } \\
\text { disediakan. }\end{array}$ \\
\hline
\end{tabular}

Tabel 4. Standar Operasional Prosedur Proses Pembelajaran

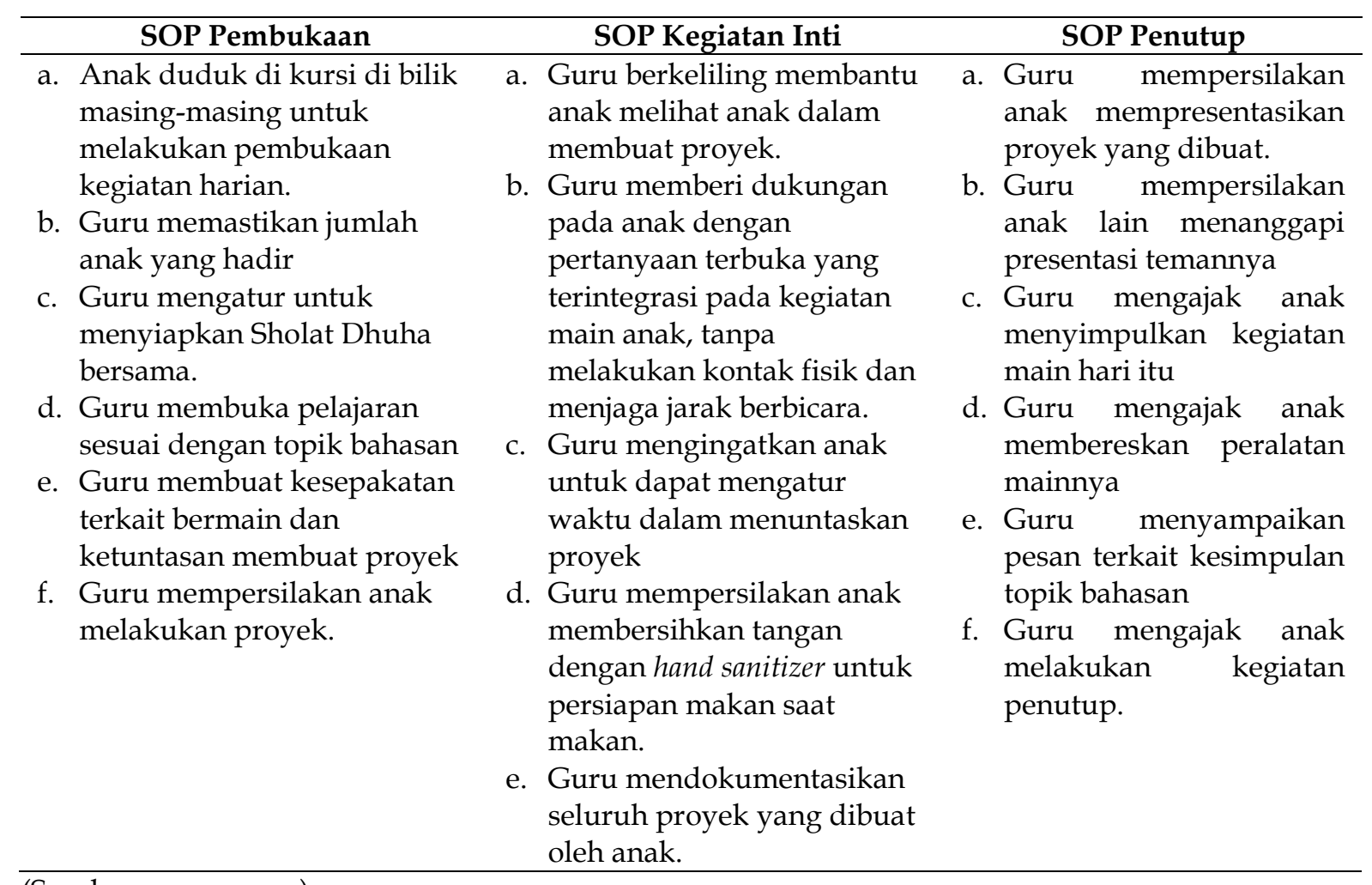

(Sumber: wawancara) 
Terdapat perubahan dalam skenario alur masuk keluar anak dan orang tua. Sebelum Pandemik, orang tua dan anak masuk dan keluar melalui pintu gerbang utama (gerbang 1). Saat pembukaan sekolah, orang tua dan anak datang melalui gerbang 2, kemudian dengan menulis presensi dan temperatur tubuh di tempat yang telah disediakan. Setelah itu setiap orang masuk ke dalam bilik disinfektan. Berikutnya anak langsung diantar masuk ke kelas, dan orang tua menuju ruang tunggu yang telah disiapkan. Guru dan siswa tidak melakukan kegiatan berbaris sebelum masuk kelas, sebagaimana yang selalu dilakukan sebelum Pandemik. Adapun skenario alur keluar (pulang) sekolah untuk kelas kelompok A langsung melalui gerbang 1, kelompok B dari kelas paling belakang menuju gerbang 2. Kelompok C juga menuju gerbang 2, namun jalannya sedikit memutar menelusuri sepanjang bangunan kelas. Alur mobilitas ditandai dengan gambar "jejak kaki" di lantai (gambar 1). Berdasarkan SOP yang ada, pada dasarnya pengaturan infarstruktur termasuk alur mobilitas manusia di PAUD Langgeng Garjita sudah memenuhi standar sesuai dengan yang ditetapkan UNICEF (Bedregal 2020).

Berdasarkan definisi dari CDC (Centers for Disease Control and Prevention) Amerika Serikat dan $\mathrm{WHO}$, pembatasan sosial (social distancing) terdiri dari dua komponen utama yaitu, menjaga jarak aman antar individu (3-6 kaki) dan mengurangi jumlah orang yang berinteraksi secara langsung. Beberapa negara mengambil kebijakan untuk mengurangi interaksi sosial di sekolah dengan mengurangi ukuran kelas, menjaga siswa tetap di dalam kelas, menjauhkan jarak antar kursi, membatalkan pertemuan berskala besar dan mengatur kembali jadwal sehingga mengurangi siswa berkumpul pada waktu yang sama (lihat tabel 1) (Melnick et al. 2020).

Mengurangi interaksi dan tetap menjaga jarak fisik diantara anak-anak pada jenjang Pra Sekolah akan sulit diterapkan dan mungkin tidak secara substansial mengurangi risiko Covid. Oleh karena itu, perencanaan program pembukaan kembali PAUD harus fokus pada strategi mitigasi yang lebih efektif. Strategi ini termasuk kebersihan tangan dan pernafasan, mencegah penularan pada staf sekolah dan keluarga, menjaga jarak fisik, menggunakan masker bagi seluruh komunitas sekolah, dan diusahakan untuk lebih banyak berkegiatan di luar ruangan. Dalam pengaturan ruangan, jendela dan pintu harus tetap dibuka untuk meningkatkan sirkulasi udara dan membatasi pengunjung yang tidak perlu ke dalam gedung (American Academy of Pediatrics 2021). Sebagai contohnya di Norwegia, otoritas kesehatan dan pendidikan mengenalkan tiga pilar utama pedoman kesehatan untuk prasekolah yaitu: (1) orang yang sakit tidak boleh berada di sekolah; (2) selalu menjaga kebersihan, dan: (3) mengurangi frekuensi kotak dengan orang lain (I, J, and E 2020).

Rekomendasi untuk tetap menjaga lingkungan sehat bagi anak di sekolah diantaranya; (a) Tetap memperhatikan kebersihan permukaan yang sering disentuh, membersihkan, dan mensanitasi mainan; (b) menghindari berbagi benda (misalnya boneka, peralatan elektronik, mainan dan lain-lain); (c) memperhatikan ventilasi agar memastikan aliran udara lancar, dan mencegah pastikel virus terkonsentrasi di dalam ruangan; (d) menyediakan tempat cuci tangan di berbagai tempat; (e) memodifikasi layout kelas dengan memperbesar jarak antar meja anak; (f) menggunakan pembatas fisik; (g) menutup ruang bersama (contohnya aula) untuk menghindari kerumunan; (i) membuat peraturan pada permainan outdoor (Centers for Disease Control and Prevention, 2021; UNICEF Europe and Central Asia, 2020). Untuk sekolah dengan kelas terbatas, pindahkan aktivitas di luar ruangan jika memungkinkan. Bagi siswa menjadi 2-3 anak untuk tetap mendukung interaksi dalam kelompok kecil (UNICEF Europe and Central Asia 2020). Sebanyak 798 sekolah di New York City menerapkan ekeperimen hibrid, dimana sekolah umum diperbolehkan menggunakan kelas outdoor dengan memanfaatkan halaman sekolah, jalan umum, dan tempat parkir sebagai pengganti ruang kelas (Day 2021). Namun demikian, PAUD Langgeng Garjita memiliki banyak ruangan besar dan ventilasi yang memadai, sehingga tidak menggunakan fasilitas outdoor sebagai tempat belajar. 
Adapun standar operasional prosedur mingguan di buat untuk menjaga keamanan dan kenyamanan berlangsungnya kegiatan belajar mengajar dengan tetap melaksanakan protokol kesehatan. Pembagian jadwalnya dijelaskan pada tabel 5.

Tabel 5. Jadwal Pembersihan Sekolah Oleh Orang Tua Dan Petugas Kebersihan

\begin{tabular}{clll}
\hline Hari & \multicolumn{1}{c}{ Waktu } & \multicolumn{1}{c}{ Keterangan } \\
\hline Senin & $06.30-07.00$ & $\begin{array}{l}\text { orang tua dan guru bersama-sama menata } \\
\text { lingkungan sekolah }\end{array}$ \\
Jumat & $\begin{array}{l}\text { Disesuaikan dengan jadwal } \\
\text { masing-masing kelas }\end{array}$ & $\begin{array}{l}\text { orang tua bersama anak membereskan semua alat dan } \\
\text { bahan permainan ke dalam box dan diletakkan di atas } \\
\text { meja } \\
\text { petugas kebersihan akan membersihkan ruangan dan } \\
\text { menyemprotkan cairan disinfektan }\end{array}$ \\
\hline Sabtu & $07.00 \mathrm{~s} / \mathrm{d}$ selesai & & \\
\hline
\end{tabular}

Perencanaan pembukaan sekolah dan pembelajaran tatap muka selain membutuhkan perencanaan yang matang, juga sudah mendapatkan ijin dari pemerintah daerah setempat. Guru dan tenaga pendidik sudah melaksanakan vaksin tahap 1 dan 2. Dalam perencanaan tersebut, diperlukan kesepakatan dan perubahan mendasar tingkat partisipasi orang tua, protokol kesehatan dan sanitasi, pola pendaftaran, dan peran guru agar terlaksana suasana kegiatan pembelajaran yang aman dan nyaman (I et al. 2020). Meskipun akan banyak tantangan, anak-anak sangat tangguh dan adaptif. Dengan adanya instruksi yang konsisten dan lingkungan pengasuhan yang jelas, maka anak mampu menyesuaikan diri dan berkembang dalam lingkingan belajar yang baru (United Nations Children's Fund, World Bank and United Nations Educational, Scientific and Cultural Organization 2020)

\section{SIMPULAN}

PAUD Langgeng Garjita akan melaksanakan pembelajaran tatap muka di masa Pandemik Covid-19, dengan menerapkan prinsip mitigasi dan adaptasi dalam bentuk integrasi protokol kesehatan $5 \mathrm{M}$ dan pembuatan standar operasional prosedur pada semua kegiatannya. Perubahan besar tampak pada proses alur masuk dan keluar siswa di lingkungan sekolah yang dibuat seefektif mungkin sesuai dengan protokol kesehatan. Perubahan juga dilakukan dengan penyekatan ruangan kelas, dan siswa memiliki alat peraga edukatif serta perlengkapan sanitasi pribadi untuk mengurangi interaksi dan mobilisasi. Mitigasi berlapis ditambah dengan keterlibatan orang tua dalam memahami prosedur yang baru adalah konsep penting dalam adaptasi pembukaan kembali sekolah aman dimasa Pandemik.

\section{UCAPAN TERIMA KASIH}

Ucapan terimakasih kami sampaikan kepada semua guru dan staff kependidikan PAUD Langgeng Garjita atas bantuannya dalam menyediakan data, waktu, dan menfasilitasi penelitian ini.

\section{DAFTAR PUSTAKA}

Alfarizi, Thafsin. 2020. "5 M Dimasa Pandemi Covid 19 Di Indonesia." Pusat Analisis Determinan Kesehatan- Kementerian Kesehatan Republik Indonesia. Retrieved May 17, 2021. http://www.padk.kemkes.go.id/article/read/2020/04/23/21/hindarilansia-dari-covid-19.html.

American Academy of Pediatrics. 2021. "COVID-19 Guidance for Safe Schools." American Academy of Pediatrics. Retrieved April 1, 2021. https://services.aap.org/en/pages/2019-novel-coronavirus-covid-19- 
infections/clinical-guidance/covid-19-planning-considerations-return-to-in-personeducation-in-schools.

Bedregal, Paula. 2020. Guidelines for Reopening of Comprehensive Early Childhood Care and Education Services in Times of COVID-19. edited by E. Narváez. Panama City: United Nations Children's Fund (UNICEF).

Bramasta, Dandy Bayu. 2021. "Sekolah Tatap Muka Dimulai Juli 2021, Ini Skema Dan Panduan Lengkapnya Halaman." $\quad$ Retrieved April 1, 2021. https:// www.kompas.com/tren/read/2021/03/31/100837965/sekolah-tatap-mukadimulai-juli-2021-ini-skema-dan-panduan-lengkapnya?page=all.

Caesaria, Sandra Desi. 2021. "Mendikbud: Tiga Aktivitas Ini Dilarang Selama Sekolah Tatap Muka." $\quad$ Retrieved April 2021. https:// www.kompas.com/edu/read/2021/03/31/132059671/mendikbud-tigaaktivitas-ini-dilarang-selama-sekolah-tatap-muka

Centers for Disease Control and Prevention. 2021. "Guidance for Operating Child Care Programs during COVID-19." Retrieved April 1, 2021. https://www.cdc.gov/coronavirus/2019-ncov/community/schoolschildcare/guidance-for-childcare.html.

Day, Adrienne. 2021. "The Case for Outdoor Schooling." Retrieved July 8, 2021. https://www.vox.com/first-person/22276681/pandemic-covid-schools-openoutdoor-schooling.

Farquhar, Jillian Dawes. 2012. "What Is Case Study Research?" in Case Study Research for Business. SAGE Publications Inc. https:/ / doi.org/10.4135/9781446287910

Gurdasani, Deepti, Nisreen A. Alwan, Trisha Greenhalgh, Zoë Hyde, Luke Johnson, Martin McKee, Susan Michie, Kimberly A. Prather, Sarah D. Rasmussen, Stephen Reicher, Paul Roderick, and Hisham Ziauddeen. 2021. "School Reopening without Robust COVID19 Mitigation Risks Accelerating the Pandemic." The Lancet 397:1177-78. https:// doi.org/10.1016/S0140-6736(21)00622-X

I, Pramling Samuelsson, Wagner J, and Eriksen Ødegaard E. 2020. "The Coronavirus Pandemic and Lessons Learned in Preschools in Norway, Sweden and the United States: OMEP Policy Forum." International Journal of Early Childhood 52(2):129-44. https:// doi.org/10.1007/s13158-020-00267-3

Melnick, Hanna, Linda Darling-Hammond, M. Leung, C. Yun, A. Schachner, S. Plasencia, and N. Ondrasek. 2020. Reopening Schools in the Context of COVID-19: Health and Safety Guidelines from Other Countries. Washington, DC.

Menteri Kesehatan Republik Indonesia. 2020. Keputusan Menteri Kesehatan Republik Indonesia Nomor Hk.01.07/Menkes/382/2020 Tentang Protokol Kesehatan Bagi Masyarakat Di Tempat Dan Fasilitas Umum Dalam Rangka Pencegahan Dan Pengendalian Corona Virus Disease 2019 (COVID-19). Indonesia.

Osman, Mohamed El Tahir. 2020. "Global Impact of COVID-19 on Education Systems: The Emergency Remote Teaching at Sultan Qaboos University." Journal of Education for Teaching 46(4):463-71. https:// doi.org/10.1080/02607476.2020.1802583

Pemerintah Kabupaten Cianjur. 2021. Surat Edaran Dinas Pendidikan Dan Kebudayaan Pemerintah Kabupaten Cianjur Nomor 420/529/Disikbud/VI/2021, Perihal Persiapan Pembelajaran Tatap Muka.

Sari, Haryanti Puspa, and Deti Mega Purnamasari. 2021. "SKB 4 Menteri, Pembelajaran Tatap Muka Dimulai Awal 2021." Retrieved April 1, 2021. https://mediaindonesia.com/humaniora/362566/skb-4-menteri-pembelajaran-tatapmuka-dimulai-awal-2021.

UNESCO. 2020. "Reopening Schools: How to Get Education Back on Track after COVID-19 | IIEP-UNESCO." International Institute for Educational Planning. Retrieved April 2, 2021. http://www.iiep.unesco.org/en/reopening-schools-how-get-education-backtrack-after-covid-19-13424. 
UNICEF. 2020. "Classroom Precautions During COVID-19 | UNICEF." Retrieved April 1, 2021. https://www.unicef.org/coronavirus/teacher-tips-classroom-precautions-covid-19.

UNICEF Europe and Central Asia. 2020. Guidance for Re-Opening of Preschools and Kindergartens Post- COVID19.

United Nations Children's Fund, World Bank and United Nations Educational, Scientific and Cultural Organization. 2020. Global Guidance on Reopening Early Childhood Education Settings. New York.

Viner, Russell M., Christopher Bonell, Lesley Drake, Didier Jourdan, Nicolette Davies, Valentina Baltag, John Jerrim, Jenny Proimos, and Ara Darzi. 2021. "Reopening Schools during the COVID-19 Pandemic: Governments Must Balance the Uncertainty and Risks of Reopening Schools against the Clear Harms Associated with Prolonged Closure." Archives of Disease in Childhood 106(2):111-13. doi: 10.1136/archdischild2020-319963. https:// doi.org/10.1136/archdischild-2020-319963

Wise, Hannah. 2020. "Here's What America's Covid-Era Classrooms Look Like." The New $\begin{array}{lllll}\text { York Times. July } & \text { Retrieved }\end{array}$ https://www.nytimes.com/2020/08/27/education/coronavirus-schools-classroomsteachers.html. 